\title{
The lean manufacturing system applied to an auto parts industry in the heavy vehicles segment
}

\author{
Carvalho Cleginaldo Pereira de * and Reis Bruno dos \\ University of the State of São Paulo - Faculty of Engineering of Guaratinguetá, Industrial Engineering Department, \\ Avenida Dr. Ariberto Pereira da Cunha 333, Pedregulho, Guaratinguetá, São Paulo, Brazil..
}

Global Journal of Engineering and Technology Advances, 2021, 07(02), 037-049

Publication history: Received on 30 March 2021; revised on 04 May 2021; accepted on 07 May 2021

Article DOI: https://doi.org/10.30574/gjeta.2021.7.2.0067

\begin{abstract}
This paper aims to demonstrate how the adoption of a continuous improvement program, based on lean manufacturing tools, can benefit the production of automotive filters for heavy vehicles, considering improved productivity and reduced operational waste, with a consequent increase in effectiveness and cost reduction. In this study we used the lean manufacturing tools, mainly kaizen and value stream mapping. During its development, the application of a kaizen project in a production line of automotive filters for heavy vehicles, aimed obtaining increased productivity and better distribution of physical space, through the reduction of rework time, reduction of downtime due to maintenance and reduction of setup time. The use of lean manufacturing tools, through the instruments presented in this study, guaranteed the viability of improvements in the productive sector. This work allowed the observation of a consistent improvement in production capacity, with productivity increase, through the improvement of the operational time and reduction of time of waste. The best distribution of physical space and the best arrangement of items used by the production process were also achieved through the consolidation of two production lines.
\end{abstract}

Keywords: Lean Manufacturing; Kaizen; Value Stream Mapping; Auto Parts

\section{Introduction}

Globalization, market growth, absorption of new production techniques, as well as constant changes in the world economic scenario and the need to remain competitive, have made companies seek ways to stand out positively and better meet their demands and the requests of their customers. Despite notable gains, even in situations of productive and financial success, large companies understand that they cannot cool their efforts and investments in continuous improvement.

To this end, [1] defines that lean manufacturing (LM) concepts have proven to be efficient in several production units in response to the most diverse internal and external demands. The LM assumes a revolutionary role in increasing production efficiency. [2] report that lean manufacturing contributes to activities governed by waste elimination and increased efficiency and productivity of industries.

In this context, it was observed that the adoption of a continuous improvement program, based on lean manufacturing tools, could act to benefit the production of automotive filters for heavy vehicles, with improved productivity and reduction of operational waste, with a consequent increase in effectiveness and cost reduction.

\footnotetext{
${ }^{*}$ Corresponding author: Carvalho Cleginaldo Pereira de

University of the State of São Paulo - Faculty of Engineering of Guaratinguetá, Industrial Engineering Department, Avenida Dr. Ariberto Pereira da Cunha 333, Pedregulho, Guaratinguetá, São Paulo, Brazil, Zip Code:12.516-410.
} 
From these analyses, it was observed the low repercussion of citations of studies related to the theme proposed by this work, realizing the need to expand the knowledge in this research area, justifying the validity of this study for the dissemination of the knowledge obtained.

By means of lean manufacturing tools, especially kaizen and value stream mapping (VSM), this study seeks to analyze the applicability of the aforementioned tools, kaizen and VSM in the increase of productivity and physical space in a production line of filters for heavy duty vehicles.

\section{Theoretical background}

\subsection{Background}

[3] mention in their studies that after the end of World War II, in 1945, Japan, in a severely compromised political and economic situation and in need of reforms for its stabilization, had the intention of seeking new means of production, different from the one observed by Eiji Toyoda, at the Ford factory, in the United States of America (USA), where the mass production system was considered the ideal production method. In 1950, in the Japanese city of Nagoya, Toyoda and Taiichi Ohno observed that this old means of production developed by Henry Ford was difficult to replicate or even to improve, therefore, a new means of production was defined.

[4] state that, for Toyota, it was necessary to create a production system that would generate efficiency and productive advantage, with great concentration on the elimination of appreciated losses in the production process and aiming to meet the varied demand of the Japanese market. To this end, the lean production system comes to meet this need.

Western countries only paid attention to the productive differential generated by LM from the 1980s, with the oil crisis. According to [2], until this period, the predominant productive means in these regions were those developed by Taylor and Ford in American manufacturing units.

Finally, [5] bring to light the existing relationship between Industry 4.0 and the LM, stating that it, with cutting-edge and effective solutions, is properly equipped with the tools to implement the LM, despite the need for large financial investment, it is clear that Industry 4.0 and the LM are not mutually exclusive and can integrate with each other, in order to obtain success.

[4] state that lean has as its main objective the reduction of time between the customer's order and the delivery of the final product, through the elimination of waste, resulting in greater effectiveness and profit. To this end, it is necessary to identify items that can add value to the product in the customer's view, to check the production system and all stages of the production process to avoid interruptions, so as to ensure that the production does not suffer downtime and that the flow follows a production system pulled by demand. The authors also mention that this type of production has a short lead time (LT), high quality standards, efficient use of resources, and the involvement of all sectors of the organization.

[3] emphasize that the LM deals with the elimination of waste continuously, systematizing the solution of problems in production. The authors further state that these activities can ensure the proper application of lean tools, they also describe that engagement is essential and determines effective and sustainable gains and improvements.

In addition to the factors cited, [3] bring as additional information the need for stability and leveling of the entire process, generating standardization so as not to create bottlenecks and focusing on reducing LT.

\subsection{The eight wastes}

Several authors, including [6, 7], after considering that LM consists of waste reduction, have defined that these wastes are not the causes of production problems but rather symptoms of these problems. The authors agree that there are seven main activities that do not add value to the product and need to be corrected. In summary, the seven wastes are characterized by:

- Overproduction: generating inventories by overproducing or producing in advance, for the authors, this is the most difficult waste to be eliminated, since it triggers other inefficiencies in the production process, whether operational or administrative; 
- Excessive stock: is related to waste of areas and excessive storage and to obsolescence costs and stock maintenance, it is important to pay close attention to intermediate stocks;

- Transportation or transference: it is a waste of time and resources through unnecessary movements that do not add value to the product;

- Defects and rework: is composed of losses due to defective material, besides the waste of several resources with rework, and materials or products that do not meet the required quality requirements;

- Unnecessary or incorrect processes: consists of waste in the processes themselves, occurring through the inclusion of extra or unnecessary operations, in addition to component, project or maintenance operations that could be improved through improvement processes;

- Unnecessary movement or displacements: waste related to unnecessary or repetitive displacements of operators; it may be related to the dynamics, layout, or to the organization of the workplace;

- Waiting time: waste resulting from the unbalance or lack of synchronism of the operations, generating idleness and accumulation of material.

In addition to the seven wastes already well determined, [7], also cite, an eighth waste, also demonstrated by [8]; this last waste takes into account the waste of knowledge, this is closely related to losses by the non-use of knowledge and human skills to assist in the elimination of other wastes, in addition to the implementation of improvements and innovations, this eighth waste is also described as the losses arising from the gaps in sharing of acquired knowledge.

\subsection{Support tools}

\subsection{1. $5 S$}

[9], in their study, bring that companies use the $5 \mathrm{~S}$ tool in order to improve their processes, controls, and organization. In this same study, it is also stated that this tool is the first ally to the goal of raising effectiveness, in addition to the standardization of practices, improvement in safety and customer satisfaction, and also in obtaining a reduction in cycle time and greater flexibility and motivation.

[10], reports that the $5 \mathrm{~S}$ tool is mainly adopted when the goal is to reduce waste, improve productivity and better cleanliness and organization of the workspace, to this end, order in space and visual guidelines assist in maintaining more consistent operating results, with 5S typically being the first lean tool implemented by companies and precedes the implementation of other techniques to optimize the parameters and structure of processes.

\subsubsection{Single minute exchange of die (SMED)}

[11] suggest that SMED emerged in Japan between 1950 and 1969, when Shigeo Shingo worked to reduce setup time by improving it, suggesting the implementation of rapid tool change (TRF) techniques. [12] describe that Shingo defined SMED as "[...] a scientific approach to reducing setup, which can be applied to any factory or equipment." [11] go on to state that setup time is defined by organization of the every change in a process for the production of the first good part of a next batch, ideally this time should be less than ten minutes so this concept dictates that any preparation of machinery for the production of a next batch should not exceed one digit minute.

\subsubsection{Total productive maintenance (TPM)}

[13] narrate that TPM started in Japan, but consolidated in the West in the 1950s, in the United States. [14], on the other hand, bring that the main concept of TPM focuses on organizational reformulation and restructuring, with the application of continuous improvement in all aspects of the productive and strategic segment. The authors claim that, in relation to machinery, TPM is interested in ensuring innovation and transformation along the production lines, through the concept of "zero breakage". $[15,16]$ expound that TPM is structured under eight fundamental pillars, each with a specific objective; these are:

- Individualized or specific improvements;

- Autonomous maintenance - Planned maintenance;

- Education and training;

- Initial control;

- Quality maintenance;

- TPM Office;

- TPM ECO. 


\subsubsection{Kaizen}

[9] propose that continuous improvement is a topic of great relevance for industries and that kaizen is a philosophy of continuous improvement based on eliminating waste based on common sense, without the use of significant financial values, conveyed by motivating the creativity of employees with the goal of improving the practices of industrial processes.

[17] state that in the corporate environment, kaizen consists of a management system aimed at maximizing profits and productivity, based on continuous improvement of the pre-existing standard, replacing it with new, more effective standards. kaizen follows 10 fundamental principles:

- All waste must be eliminated;

- Continuous improvement must be applied;

- It must involve all employees, from managers to the operational team;

- It is based on strategies without significant investments, where the solutions act in already existing processes, reducing the need for high investments;

- It applies to various organizational models, not to companies with an exclusively eastern mentality and management style;

- It is based on transparency of processes and values, supported by visual management, allowing the problems to be perceived by everyone in the organization;

- It focuses attention on the main points of value creation within the company, mainly the operational environment;

- It is process oriented;

- It prioritizes the organization's human resources, justifying that improvement must start with the creation of a new mentality and work style;

- It values learning through practice.

Also according to [17] the kaizen program can be divided into three segments: management-oriented kaizen, grouporiented kaizen and person-oriented kaizen.

Group-oriented kaizen has two approaches; permanent and temporary. The permanent approach uses the plan-docheck-act (PDCA) cycle, which looks at identifying the problem and recognizing its causes, followed by analysis and implementation of corrective measures until new definitive standards are installed for a given process. In the temporary approach, teams are formed to act in the resolution of specific problems, usually with special attention to the use of statistical and analytical tools, and when the expected result is achieved, these teams are disbanded.

\subsubsection{Value stream map (VSM)}

[18] state that VSM is one of the fundamental principles to eliminate the waste generated by the inadequate production process. A value stream consists of every activity necessary to obtain a product ready for delivery to the customer, which will generate value for the company, despite the waste in the process. Every value stream can be mapped and from these maps it becomes possible to observe the waste and in further observation, to obtain a second graphical element that displays the desired value stream map.

[19] state that the VSM has as main results the reduction of LT and increase in productivity, being one of the most applied techniques when seeking the adaptation to a production system that follows the lean methodology, so that when waste is identified from the analysis of the production line, it establishes the use of other lean tools in order to promote the appropriate corrections, therefore it is considered the VSM as the starting point of the LM. The authors also bring as additional information about the VSM practice some proposals to incorporate discrete event simulation to the traditional technique, a fact that allows simulating and predicting the process performance indicators in a dynamic way.

[20] dissertate on the existing relationship between VSM and kaizen, clarifying that kaizen projects act to establish a link between the current state map and the future state map. 


\section{Material and methods}

\subsection{Project description}

The event under study lasted five days, held in the period from September 7 to 11, 2019. For the kaizen week to be held, the company in which this work was executed, provided a professional responsible for the event, with a location chosen by the company's top management in conjunction with the sector management, according to the company's needs. The team chosen for the event was composed of 11 collaborators from several sectors of the company, including some belonging to the sector where the improvement work was developed. The manager responsible for the sector, a production employee with advanced knowledge of all the workstations in the sector in question, and the sector processor participated. The other members belonged to other sectors such as engineering, safety, maintenance, quality, planning, and sales. The kaizen week activities started with the charter presentation, where the goals and objectives were noted, as well as the deliverables of the week, described below:

\subsection{Goals and objectives}

- Increase productivity from 17 parts/hour.men to 26 parts/hour.men;

- Reduce rework time from 3.5 hour/month to 1.5 hour/month;

- Reduce line down time for maintenance from 2.5 hour/month to 1.0 hour/month;

- Reduce average setup time from 20 minutes to 5 minutes.

\subsection{Deliverables}

- Move products from the 225 and 600 series line to the 400 and 700 series line;

- Takt time update;

- Change of leak test;

- Implementation of TPM instructions in the main machines;

- Tightening machines capability study.

\subsubsection{Product correlation matrix}

At first, all products were inserted in a correlation matrix, in order to identify points of intersection, allowing the recognition of similarities between processes. From this correlation it is possible to identify if the analyzed products will be able to be consolidated into a single value stream.

\subsubsection{Choice of layout}

The choice of the layout was based on the intersection of the products presented in the correlation matrix.

\subsubsection{Takt time determination}

After the layout choice, a process chronoanalysis was performed in order to verify if the new manufacturing time would meet the takt time. This analysis was done by measuring 125 pieces during 1 hour of production.

From this analysis, process improvements were made in order to reduce the bottleneck times using the kaizen tool.

\subsubsection{Reduction of rework hours}

125 leakage tests were performed using the dry test device, in order to validate it.

\subsubsection{Reduction of maintenance downtime}

TPM tools were applied in order to reduce the amount of downtime for corrective maintenance.

\subsubsection{Validation of the torque wrenches' capability study}

A torque capability study of the nut runners was performed by monitoring 125 executions. The values obtained were entered into Minitab® software. 


\section{Results and discussion}

\subsection{Correlation matrix of the products}

After applying the correlation matrix, the process intersection was identified in $90 \%$ of the produced items. The products that did not fit this correlation matrix suffered phase out or outsourcing.

\subsection{Choice of layout}

Previously there were two production lines, series 225 and 600 and series 400 and 700, as shown in Figures 1 and 2.

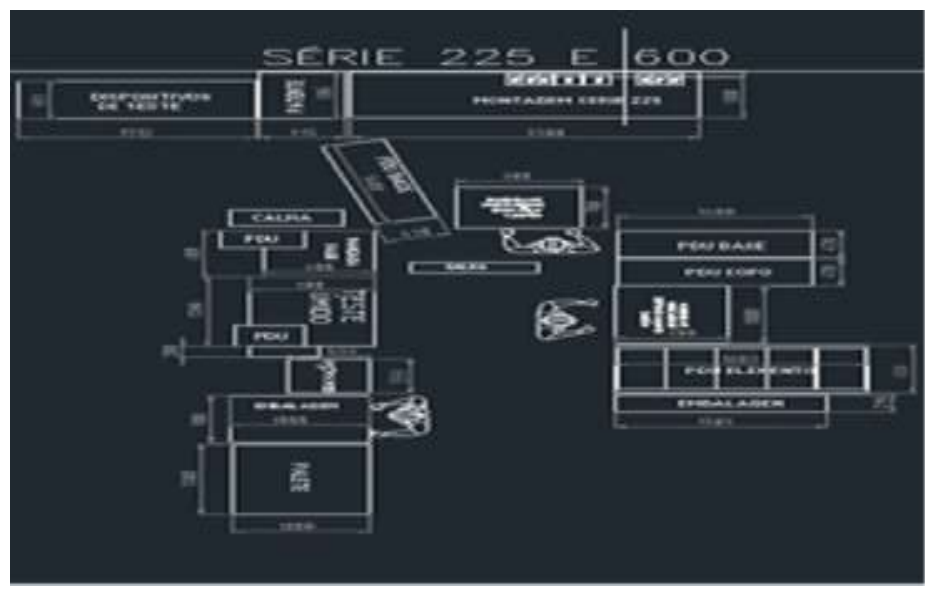

Figure 1 Production layout Series 225 and 600. Source: Author's

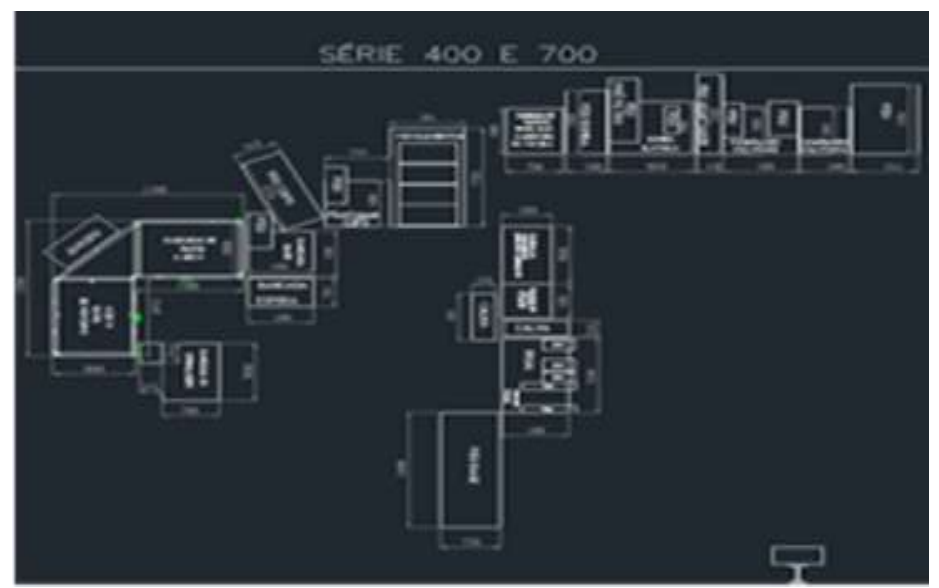

Figure 2 Production line series 400. Source: Author's

After structuring the correlation matrix, previously cited, it can be observed that both processes of the 225 and 600 series production lines and the 400 and 700 series production line could be performed in a single line, using the current layout of the 400 and 700 series production line, previously demonstrated in Figure 2.

\subsection{Takt time}

After moving all products to the 400 and 700 series production line, it was possible to observe, as per Figure 3 , that the initial process time was 45 seconds (operation 4 - OP4). 


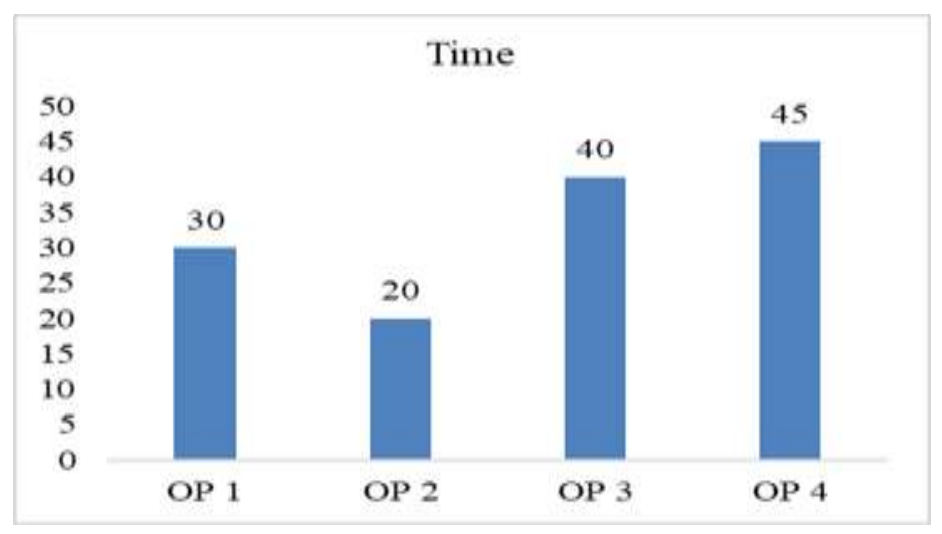

Figure 3 Initial takt time. Source: Author's

This initial time of 45 seconds did not meet the customer's takt time, therefore, improvements were applied in the operations, with results described below.

\subsubsection{Improvement of operation 4: change of the leak test system}

The tightness test was performed via wet test, where the parts were submerged in a tank with a pressure of 3 bar, process demonstrated in Figure 4; with the need of visualization by the operator to ensure the part's tightness.

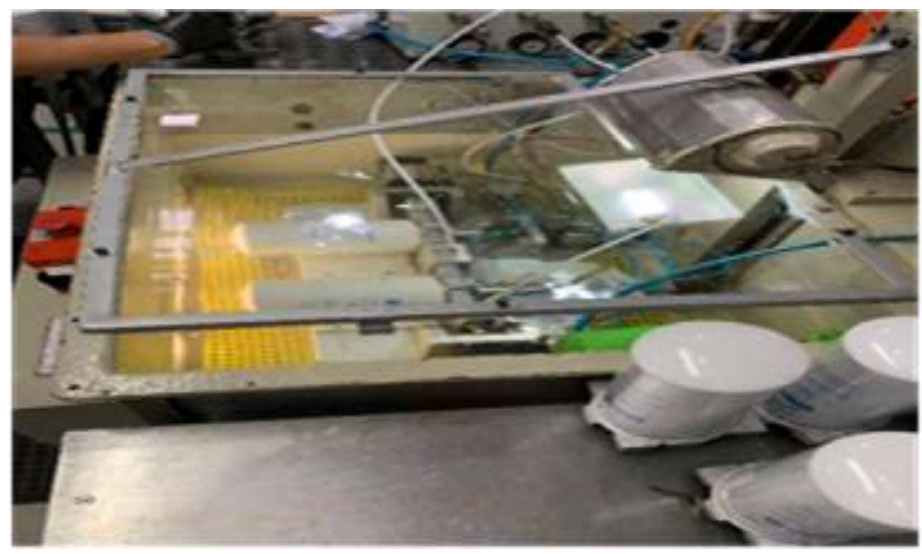

Figure 4 Immersion tightness test. Source: Author's

A dry test system was installed, as shown in Figure 5, where the part's tightness is automatically analyzed by comparison with atmospheric pressure.

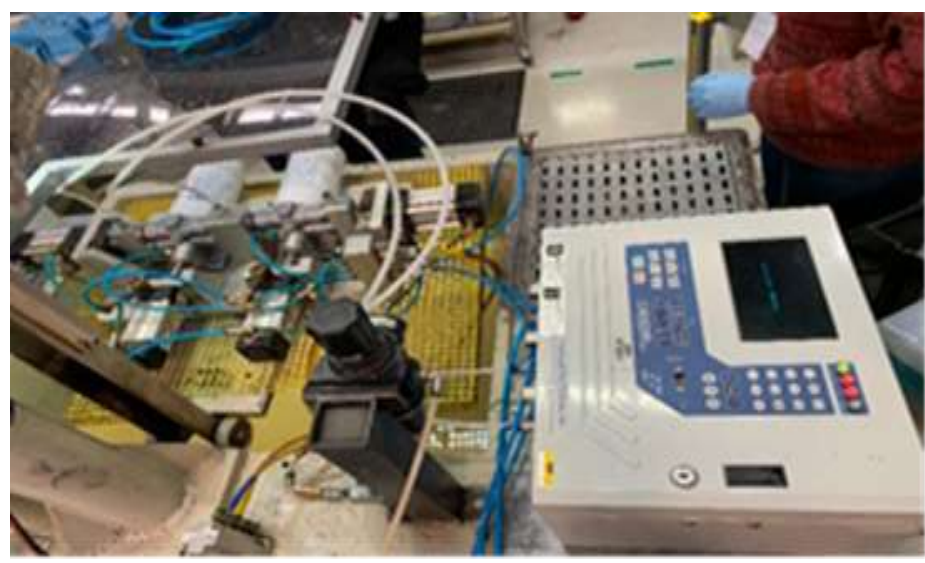

Figure 5 Dry tightness test device. Source: Author's 
After the dry test device was installed, it could be observed that the operator 4 no longer needed to be tied to the visualization of the test, freeing him to perform parallel activities, reducing the operation time from 45 seconds to 30 seconds.

\subsubsection{Operation 3 (OP3) improvements}

Unification of drain and sensor squeezers

Previously the operator used two different nut runners to perform the torque on the drain and sensor, according to Figure 6.

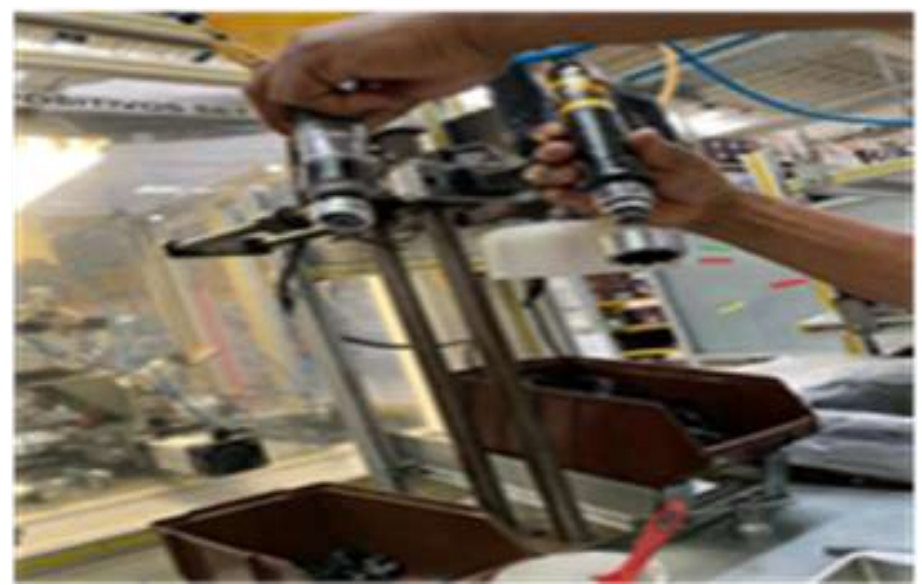

Figure 6 Use of two nut runners for drain and sensor. Source: Author's

A device was developed, as per Figure 7, which enabled the use of a single nut runner for both components.

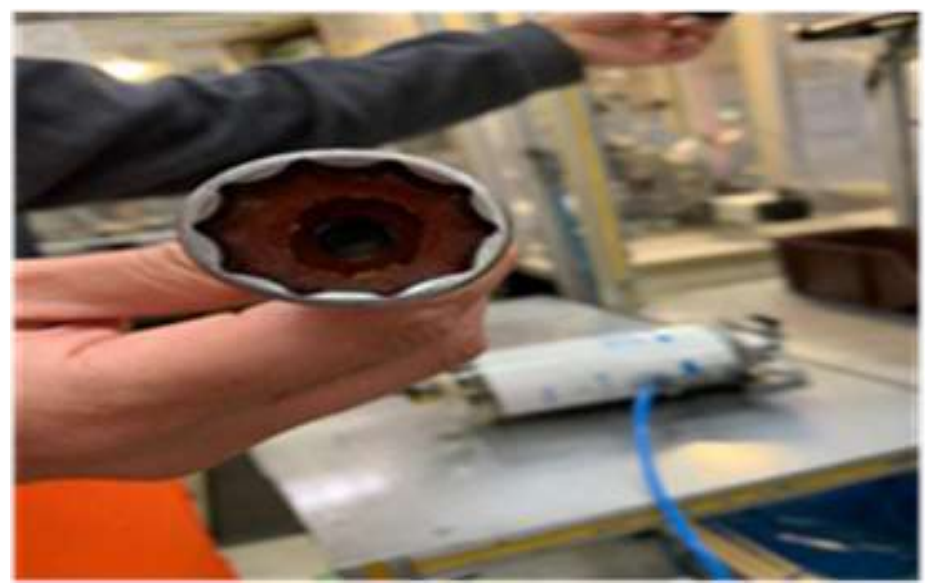

Figure 7 Dual functionality device. Source: Author's

Unification of the cup and base torque stations

Previously the operator performed two torque operations at different stations, according to Figure 8, since their values were different. 


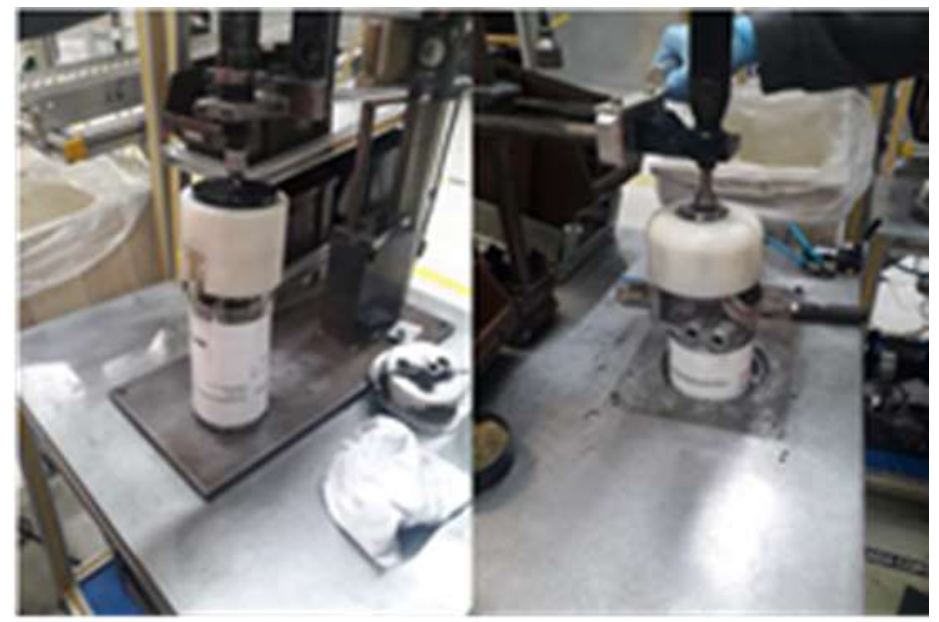

Figure 8 Cup and base operations. Source: Author's

The stations were unified into a single process, according to Figure 9, using a single torque value for base cup assembly.

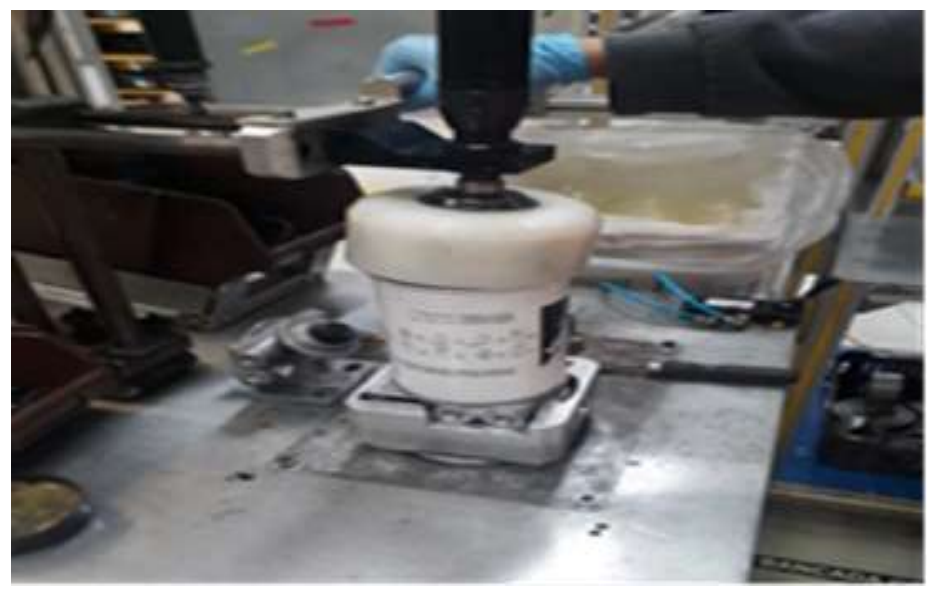

Figure 9 Unified torque station for the cup and base. Source: Author's

After the improvements were finalized, the assembly time for operation 3 was reduced from 40 seconds to 35 seconds.

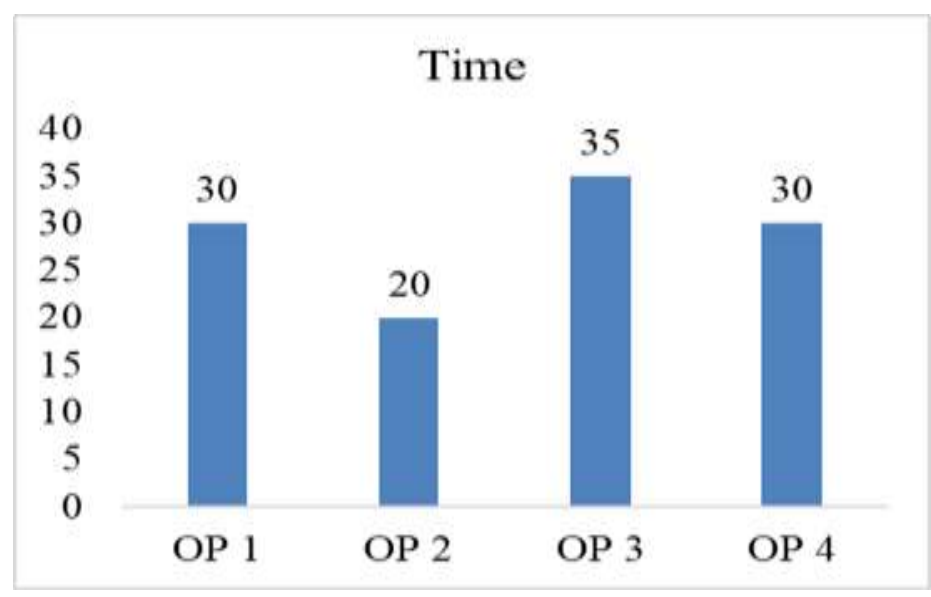

Figure 10 Final takt time. Source: Author's

Thus, the takt time was reduced to 35 seconds, as shown in Figure 10, and it became possible to achieve the goal of 26 parts/hour.men. 


\subsection{Validation of the dry test device}

Process validation was performed for the use of the dry test, shown previously in Figure 5, which has a tolerance of 6 cubic centimeters per minute. The immersion test had no tolerance, since it was performed visually by the operator, allowing false rejects and causing rework time.

After validation, the false reject was eliminated, reducing the rework volume to 1.5 hour, according to Figure 11.

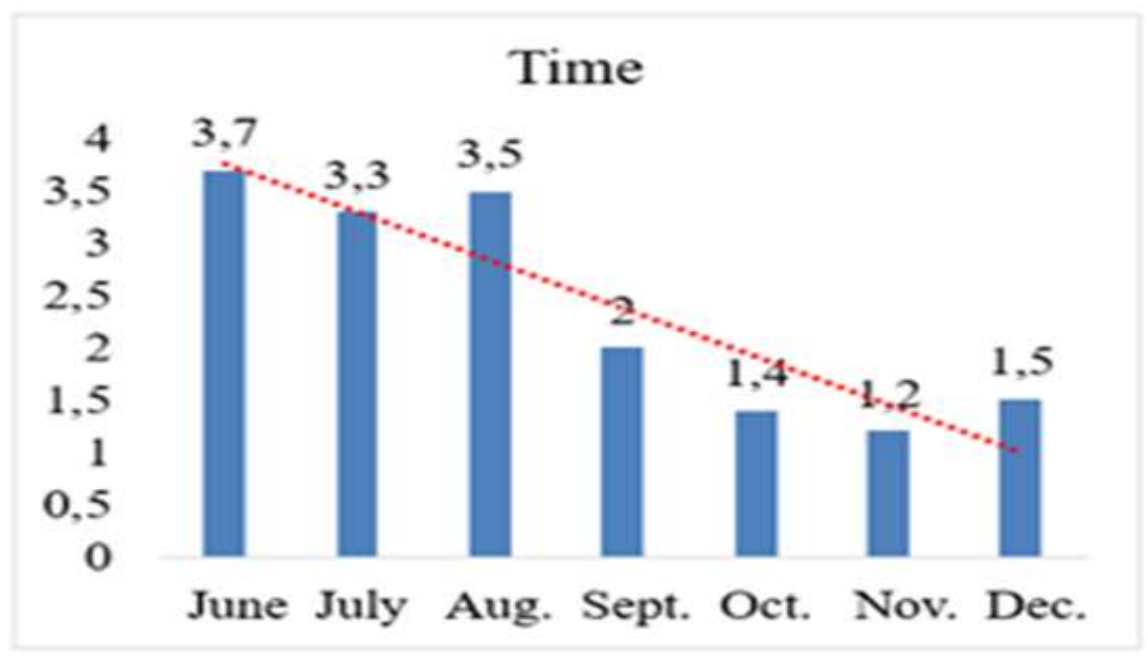

Figure 11 Trend of monthly rework hours. Source: Author's

\subsection{TPM implementation on the 400 and 700 series production line equipment}

TPM instructions were implemented, according to Figure 12 and check list, aiming at reducing the time of line stoppage for maintenance.

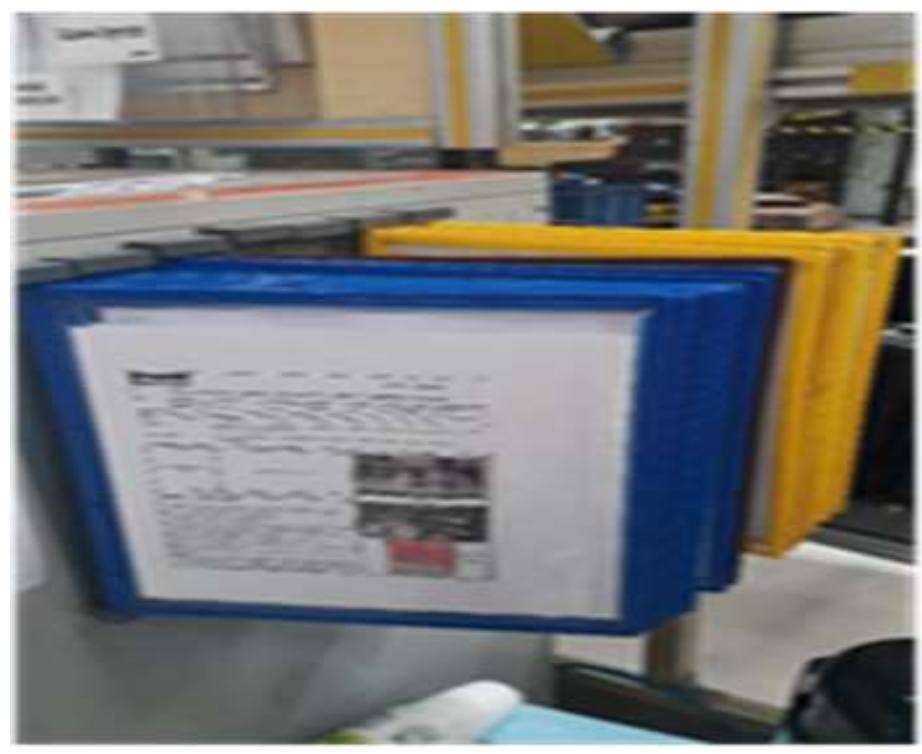

Figure 12 TPM instruction. Source: Author's 


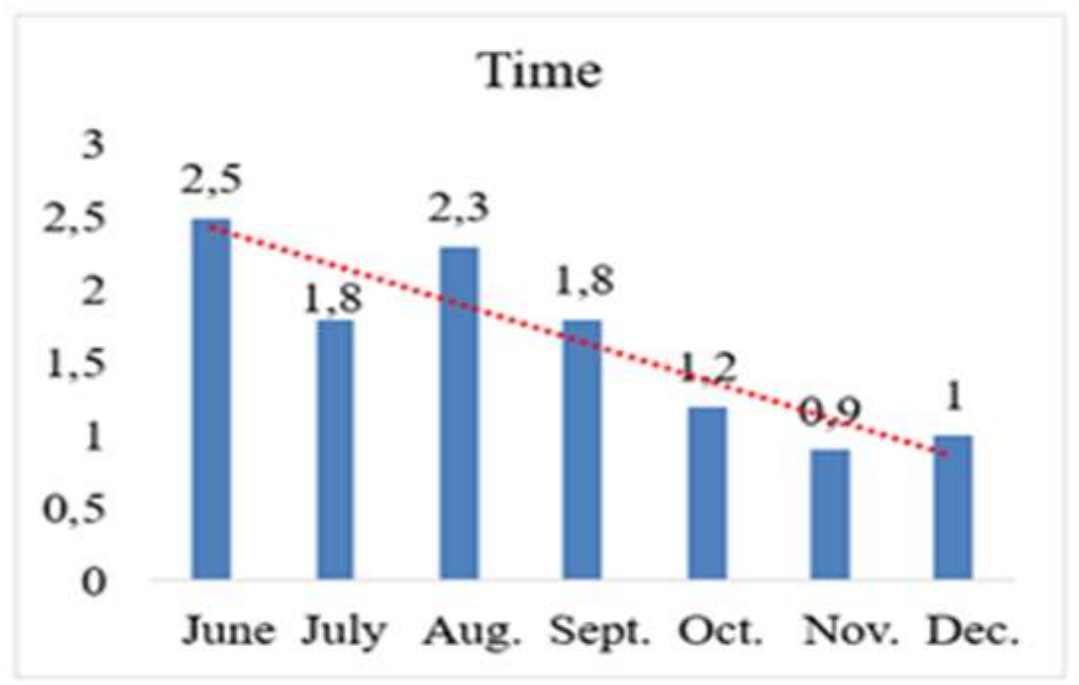

Figure 14 Trend of monthly hours of line stoppage by maintenance. Source: Author's

After the TPM implementation we can observe the reduction on the monthly volume of maintenance stoppage hours, according to the Figure 14.

\subsection{Validation of the nutrunner capability study}

Previously, it was necessary to check the torque of the nutrunners at the beginning of each work order, since it is considered a critical characteristic of the product. This constant torque calibration caused a high volume of setup hours.

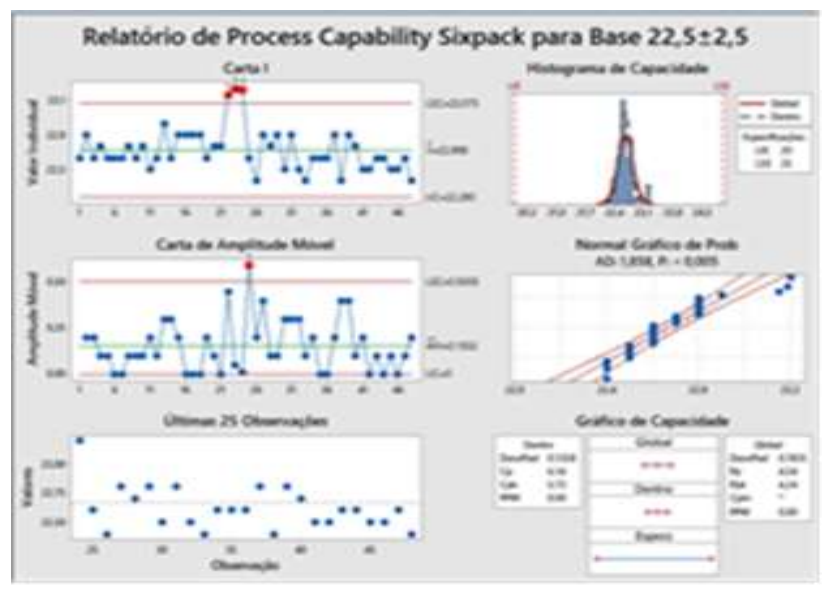

(a)

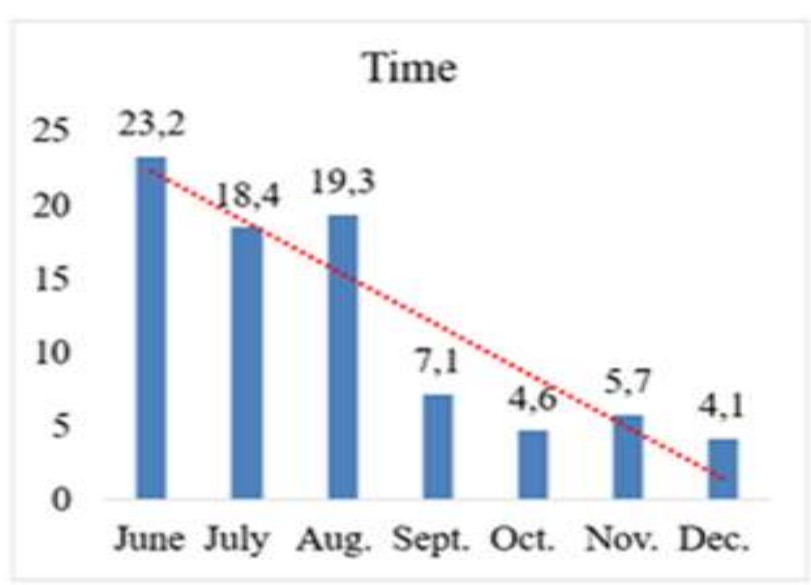

(b)

Figure 15 (a) and (b) - (a) Squeezers capability results; (b) Trend of average setup time. Source: Author's

After the nut runners capability studies, according to Figure 15 (a), it was possible to verify that the equipment had a process capability of 5.72, i.e, they were capable.

From this study, the torque calibration process was validated to be performed only at the beginning of each shift, thus reducing the average setup time, according to Figure 15 (b).

\section{Conclusion}

The use of lean manufacturing tools, through the instruments presented in this study, guaranteed the viability of improvements in the production sector. The present document allowed the observation of consistent improvement in the productive capacity, being obtained an increase in productivity to 26 parts/hour.men, through the improvement of 
the operations time and reduction of waste time, such as rework, corrective maintenance and setups. This set of factors allowed the achievement of the consolidation of the production lines in question, as per the premise of the work.

The present study demonstrates that the tools used can be applied in the productive practice, guaranteeing good results, with improvement in the productive capacity and consequent improvement in the profits and resources obtained. This work can be used as a reference for further good practices for kaizen projects in other sectors of the company in which this project was conducted, and also in other business units that show interest in the improvement of productive aspects.

The limitations of this study were the possibility of approaching a single production line. It is considered that the ideal methodology for the validation of the concept exposed in this document consists in the expansion of the proposed model in more production lines, also considering the inclusion of other production segments. It is also considered a limitation the non-use of simulation tools during this study, an element that would allow a better observation of variables and results, besides extrapolating these results to other production lines and manufacturing segments.

As a suggestion for future work, we suggest the use of process simulation software, which could offer a range of interactions and testing opportunities without influencing the direct fulfillment of production demands and would enable the validation of the concept of the tools discussed in this study.

\section{Compliance with ethical standards}

\section{Acknowledgments}

Authors wish to acknowledge the University of the State of São Paulo, Faculty of Engineering of Guaratinguetá - São Paulo - Brazil, for its assistance during the research period.

\section{Disclosure of conflict of interest}

Authors of the article claims that he has no conflict of interest.

\section{References}

[1] Santos PVS. Previsão da Demanda como Suporte à Filosofia Lean. Revista Exacta. 2020; 18(1): $226-243$.

[2] Vargas TB, Pinto GA. Lean Manufacturing, Flexibilidade e a Indústria Brasileira. Ideação, Revista do Centro de Educação, Letras e Saúde, Foz do Iguaçu. 2019; 21(2): 159-175.

[3] Aniceto GS, Siqueira CMA. Importância do Sistema Toyota de Produção para o Desenvolvimento de Empresas de Seguimentos Diversos. Revista UNIVAP. 2016; 22(40): 587.

[4] Pedroso LB, Isoppo A, Bitencourt J, Pacheco DAJ. Implicações da Mapeamento de Fluxo de Valor na Indústria. Latin American Journal of Business Management. 2015; 6(3): 3-19.

[5] Sanders A, Elangeswaran C, Wulfsberg JP. Industry 4.0 implies Lean Manufacturing: Research Activities in Industry 4.0 Function as Enablers for Lean Manufacturing. Journal of Industrial Engineering and Management, JIEM, OmniaScience. 2016; 9(3): 811- 833.

[6] Vasconcellos LHR, Ferreira FCM, Santos MS. A Relação das Práticas do Lean Manufacturing e o Desempenho operacional: um Estudo no Setor de Autopeças. Revista Gestão e Tecnologia. 2019; 19(5): 276-295.

[7] Soares PC, Silva RC, Schiavon LCM. Resultados Obtidos com a Implementação de Conceitos de Lean Manufacturing em uma Indústria Metal- Mecânica. Revista Produção em Destaque. 2017; 1(1): 484-508.

[8] Muniz JRJ. Modelo Conceitual de Gestão de Produção na Gestão do Conhecimento: um Estudo no Ambiente Operário da Indústria Automotiva. Tese de Doutorado, Faculdade de Engenharia do Campus de Guaratinguetá, Universidade Estadual Paulista. 2007.

[9] Carvalho CP, Gonçalves LWN, Silva MB. Kaizen and 5S as Lean Manufacturing Tools for Discreat Production Systems: A Study of Feasibility in a Textile Company. International Journal of Research Studies in Science, Engineering and Technology. 2017; 4(7): 1-12.

[10] Al- Aomar RA. Applying 5S Lean Technology: An Infrastructure for Continuous Process Improvement. World Academy of Science, Engineering and Technology. 2016; 60: 1606 -1611. 
[11] Vale VM, Brito JN. Aplicação da Single Minute Exchange of Die em uma Máquina de Solda Projeção. Revista de Trabalhos Acadêmicos Lusófona. 2019; 2(2): 255-270.

[12] Sugai M, Mcintosh RI, Novaski O. Metodologia de Shigeo Shingo (SMED): Análise Crítica e Estudo de Caso. Gestão da Produção. 2007; 14(14): 323-335.

[13] Silva MA, Azevedo FG, Ferreira FG. TPM e Manutenção Autônoma: Estudo de Caso em uma Empresa de Pintura no Ramo Automotivo. Revista Eletrônica Estácio Recife. 2019; 5(5): 1-10.

[14] Coimbra EA, Prudêncio RAN, Correia JPS, Prudêncio RLN, Grilo GWO. Implantação da Manutenção Produtiva Total em uma Empresa Automobilística do Sul de Minas Gerais. Revista Produção em Foco. 2019; 2(19): 1-15.

[15] Nascimento DM, Diniz HHL, Gabú ABS. Manutenção Produtiva Total (TPM): Estudo de Caso em uma Indústria de Bebidas. Revista de Trabalhos Acadêmicos Universo Recife. 2017; 4(2-1): 1-18.

[16] Menezes GS, Santos MMN, Chaves GLD. O Pilar Manutenção Planejada da Manutenção Produtiva Total (TPM): Aplicação da Manutenção Centrada em Confiabilidade (RCM). Revista Gestão Industrial. 2015; 11(4): 1-35.

[17] Oliani LH, Paschoalino WJ, Oliveira W. Ferramenta de Melhoria Contínua Kaizen. Revista Científica UNAR. 2016; 12(1): 57-67.

[18] Carvalho CP, Carvalho DS, Silva MB. Value Stream Mapping as a Lean Manufacturing Tool: A New Account Approach for Cost Saving in a Textile Company. International Journal of Production Management an Engineering. 2019; 6(2): 1-12.

[19] Lima DFS, Alcantara PGF, Santos LC, Silva LMF, Silva RM. Mapeamento do Fluxo de Valor e Simulação para Implementação de Práticas Lean em uma Empresa Calçadista. Revista Produção Online. 2016; 16(1): 366-392.

[20] Kumar S, Dhingra AK, Singh B. Process Improvement Through Lean- Kaizen Using Value Stream Map: a Case Study in India. The International Journal of Advanced Manufacturing Technology. 2018; 96: 2687- 2698. 